DOI: 10.1515/auseur-2017-0004

\title{
Understanding the Narratives Explaining the Ukrainian Crisis: Identity Divisions and Complex Diversity in Ukraine ${ }^{1}$
}

\author{
Lodewijk SMOOR \\ Department of European Studies \\ University of Amsterdam \\ lsmoor@hotmail.com
}

\begin{abstract}
The central argument of this paper is that radical and opposing interpretations of the Ukrainian conflict in politics and media should be studied as offspring of broader narratives. These narratives can be better understood by examining the national identity of Ukraine. Since Ukrainian national identity shows a high degree of diversity, it offers a rich source of arguments for any party wanting to give an interpretation of the present Ukrainian crisis. Narratives explaining the crisis often ignore this complex diversity or deliberately use elements from it to construct the 'desired' narrative.

Firstly, this paper defines four overarching narratives used in the current debate: the geopolitical, the nationalist, the structuralist, and the legal narrative. Secondly, this paper shows how various interpretations fitting within these narratives are all one way or another related to the divisions dividing Ukraine's complex national identity. Examining the underlying divisions helps to explain the appeal of differing interpretations of the conflict in the West, Ukraine, and Russia. Especially the nationalist narrative and geopolitical narratives show how the complexity of Ukraine's national identity is deliberately used to construct a narrative.

The combined study of constructed narratives and Ukrainian national identity thus provides valuable material for any scholar or policymaker looking for a deeper understanding of the situation in Ukraine amidst a confusing information war.
\end{abstract}

Keywords: Ukraine, national identity, language policy, regional identity

1 Working paper presented at the Conference on Patterns of Integration of Old and New Minorities in a Europe of Complex Diversity held in Cluj, 8-9 November 2015. 


\section{Introduction}

\subsection{A Range of Arguments}

Is Ukraine, a 'fascist-ruled state suppressing its Russian minority' as some Russian media state? Or is it 'a corrupt state with a dysfunctional economy ruled by extremists' as was put forward by opponents of the EU-Ukraine association treaty in the Dutch referendum campaign? Or is it a victim of geopolitics and weaknesses in international law as some observers of international relations and international law put it? These are just a few of the numerous, often conflicting characterizations of the Ukrainian crisis, which evolved after the rejection of the agreement between the EU and Ukraine by President Yanukovych, the subsequent Maidan revolt, and the continuing political and military upheaval in Crimea and Donbass.

In the information war (Voswinkel 2014) erupted soon after the Maidan protests started, Russian government officials tended to portray the events in Kiev as nothing less than a fascist coup d'état, orchestrated by Western powers, with the intention of undermining the position of Russia. This discourse was taken over by state-controlled or -subsidized media, such as Russia Today (Starink 2015: 232, Geisbuhler 2014: 21). A geopolitical narrative was constructed, in which Western powers were portrayed as untrustworthy and insensitive towards Russia's position in the world and its 'justifiable interests'. The West actively supports regime change and ultimately wants regime change in Russia (Katz 2015: 58). Signs of Russophobia, especially in countries formerly part of the Soviet Union, were brought to the attention of the public in Russia and led to an additional nationalist narrative in Russian media about the suppression of Russia and glorification of Russian historical achievements. The provisional Ukrainian government, which took office after Maidan, was labelled as fascist, anti-Russian, and nationalistic. In Russian media, its supporters were portrayed as villains and NATO puppets. This narrative also made its way to Western media and more radical political parties in the West on both sides of the political spectrum (Hausmann \& Penter 2014: 39). In turn, leading Maidan politicians depicted Russia as an imperial aggressor led by a dictator and pursuing a neoSoviet policy that is patronizing towards former parts of the Soviet Union with a Russian minority (Bomsdorf: 2015).

In Ukraine, following the geopolitical frame, Russia was portrayed on social media, such as Vkontakte and Facebook, as an aggressive, imperial power. It was frequently claimed that Russia ignores international law and is opposed to a truly independent Ukrainian state (Wilson 2014: 68-70). Ukraine added a new narrative, that of the international legal order. This narrative also stressed the autonomous internal development of Ukraine, away from corruption and Soviet legacies, towards 'the European model'. Each new argument provoked a 
counterargument from the other side, which led to a confusing and clamorous debate. This so-called 'information war' has fuelled the conflict, which has become a dangerous mixture of nationalism, political psychology, geopolitics, economic considerations, and perceived national interests. It is therefore hard to separate facts from constructed narratives.

\subsection{Overarching Narratives and National Identity}

This working paper proposes a clarifying framework to interpret these arguments because conflicting arguments and disinformation may lead to oversimplifications in public debate and distrust in political communication (Pesenti \& Pomeranchev 2016: $2-5) .^{2}$ First, this paper identifies four frequently used overarching narratives: the nationalist, the geopolitical, the structuralist, and the legal narrative. This typology is based on research into existing narratives about Ukraine's national identity (Korostelina 2013) and secondary literature describing the positions of Russia, Ukraine, and others in the conflict (Smeets 2015, Wilson 2014). The aim of this paper is to understand how these narratives are constructed and why they are successful. In order to address this question, this paper explores the relationship between the four overarching narratives and different manifestations and interpretations of Ukraine's national identity.

\subsection{National Identity as Explanatory Variable}

Ukraine's complex national identity is a wellspring of various competing narratives (Korostelina 2013). This paper will argue that images and constructed identities play a crucial role in the narratives used to mobilize support for the different positions in the conflict. Scholars addressing the on-going Ukrainian conflict often fail to address the complex national identity issues in Ukraine. This is a missed opportunity since historical experiences continue to shape the behaviour of political elites in East-Central Europe (Subtelny 2011: 20). In addition, national identity shapes the receptivity of their public to different narratives. Memories of humiliation and heroic struggles in the process of national identity formation remain prominent in East-Central Europe. A viable independent Ukrainian state was not realized until 1991 after centuries of being part of the Habsburg and Russian empires and the Soviet Union. Hence, the formation of a Ukrainian nation-state is still in its early phase and historic and societal divisions are still very tangible.

In the case of Ukraine, many authors (Pirie 1996, Janmaat 2000) have pointed out the relevance of various types of self-identification (e.g. mixed, Russian,

2 Since the start of the conflict, private and public initiatives, such as stopfake.org, have been taken to counter fake news or to communicate with Russian speakers, such as EU-funded TV channels and an Estonian state television channel in Russian. 
Ukrainian, other), the effects of mixed marriages as well as the importance of historical roots of competing identities and their impact on visions of Ukraine (Riabchuk 2012). The interaction between national identity and foreign policy is particularly important in newly emerging or re-emerging states because nationalism and national identity are the main centripetal and centrifugal forces (Prizel 1998: 2). The fragmented Ukrainian national identity in no small part determines its international behaviour (Molchanov 2002: 280). Shulman (2004) found that national identity has an impact on political attitudes. Therefore, a closer examination of national identity is conducive to understanding the narratives used in the information war. It reveals the deep historical roots of political fragmentation (Molchanov 2002: 188). History and its interpretation are important explanatory variables for political behaviour in East and Central Europe (Hausmann \& Pentner 2014: 46). The examination of Ukrainian national identity will also compensate for the lack of attention for Ukraine because it was considered more important by the West than Russia and as an impediment to attempts to improve relations between Russia and the West (Jansen 2014: 171, Portnov 2014).

\subsection{Narratives}

In an information war, both sides use radical interpretations and (over) simplifications to convey their political message. Not surprisingly, contentions in the information war are often diametrically opposed. A factual assessment of some of these contentions has already been made by Andrew Wilson (2014) and Yekelchyk (2015). This paper treats these contentions as stemming from overarching narratives which are used to convey a message in a convincing and coherent manner. These narratives stem from ideological and economic considerations, differing value orientations and radically diverging interpretations of history. In other words, these interpretations make selective use of elements from Ukrainian national identity and Ukrainian history.

Even before the information war broke out, various narratives existed about Ukraine's national identity (Korostelina 2013). These narratives were amplified in the actual information war between Ukraine and Russia. This working paper is an attempt to structure and explain the arguments put forward in four overarching narratives. It describes them below as existing competing ideologies mirrored in political and media discourse. Each narrative can be loaded with arguments. Each narrative can be used by both camps, only the arguments used will vary. This is exemplified by references to contentions based on the narrative created by both camps. Further research is needed in order to test the existing narratives and to further explore the new ones. 


\section{Narratives}

\subsection{Nationalism}

In the nationalist narrative, the conflict is framed as a clash of Ukrainian and Russian nationalism, in which both sides emphasize their national interests. These national interests are constructed and often justified by arguments based on the interpretation of history, in which recurring elements are World War II, victimization, and the Russian world. Ukraine argues that its 'otherness' is not recognized and claims that Russia interferes in Ukrainian matters such as changing its government or preferring an agreement with the EU to an agreement with Russia. On the other hand, Russia argues that the interests of Russian citizens are seriously threatened. It disputes the legality of the changes in the Kiev government, thereby invoking historical arguments, which imply that Ukraine and Russia are by definition intertwined and cannot take different paths (Jahn 2015).

Typical arguments within this narrative, which were voiced, among others, on Russia Today, Russian state television, and in press releases and addresses of Russian government officials, such as the Russian representative in the UN security council, Foreign Secretary Lavrov, and President Putin, are that Crimea is Russian, as Putin stated while addressing the State Duma on 18 March 2014). ${ }^{3}$ The message that Russian speakers in Ukraine had been discriminated and Russians in Ukraine had been in danger was disseminated in various Kremlin press statements. ${ }^{4}$

A recurring geopolitical theme are the 'extreme right' or 'fascist' forces inspired by Stepan Bandera and paid by foreign powers who are 'dominating' the new Ukrainian government (Hausmann \& Penter 2014: 38). On the other side, Western observers, such as Wilson and the Ukrainian state media, held that Russia has shown in history that it is ambivalent in recognizing Ukraine as a sovereign country.

\subsection{Geopolitics}

The geopolitical conflict narrative is constructed on a perceived ideological clash between the Russian world with its Slavic or Eurasian 'traditional and authoritarian' values on the one hand and the Western World with its liberal 'decadent and double-sided' Western values (Gray 2014, Wilson 2014, Krzeminski 2015) on the other.

3 See also the website of the Russian Ministry of Foreign Affairs www.mid.ru for more examples of geopolitical interpretations of the conflict.

4 See en.kremlin.ru. 
In this global game, the focus is not on Ukraine but on the West and Russia disputing each other's spheres of influence, invoking memories and images from the Cold War. In this narrative, recurring references are made to alleged attempts to restore the Soviet Union, encirclement of Russia and 'interests' partly justified by earlier humiliations (Wilson 2014: vii, 13). Russia also fights an ideological war with 'homosexual decadency', the liberal West, and 'the dictatorship of the US' (Starink 2015: 238). The aim of Russia is to prevent a unipolar world dominated by the US by creating a multipolar world. Smaller states can be seen as pawns.

Typical arguments within this narrative are that Russia was humiliated by Western powers and deserves its sphere of influence (Creuzberger 2015). In a similar fashion triggered by the Cold War rhetoric on the Russian side, it was thought that Russia tried to restore the Soviet Union. A common argument among Western observers is that Russia is interfering in internal Ukrainian affairs. Ukrainian politicians underline that Ukraine should be able to choose independently from Russia. On the other hand, most Russian media choose a radically different frame, following the interpretation that Ukraine under Yanukovych was not allowed by the West to enter an agreement with Russia because the West wanted to control Ukraine (Portnov 2014: 6).

\subsection{Structuralism}

In the structuralist narrative, the crisis in Ukraine is attributed to the particular economic and social structure of Ukraine, characterized by lack of domestic political cohesion. Ukraine is portrayed as having an inflexible, oligarchic economy, weak institutions, and high levels of corruption. Korostelina describes independent Ukraine as a façade democracy with a court and a parliament but in which important decisions are made informally (Korostelina 2013: 39).

Ukraine is prone to centrifugal regional forces and lacks unity (see Karácsonyi et al. 2014). Ukraine has a predatory elite presiding over a deeply divided society (Wilson 2014: 39). Ukraine did not unequivocally take the path of other EastCentral European and Baltic states and remained internally divided along various lines. In this respect, it resembles the situation in pre-war Poland and the pre1795 Polish nobles' republic.

In addition to institutional economic factors, another key structural variable is the change of attitude within Ukraine. The shift from a 'homo sovieticus' towards a more $21^{\text {st }}$-century type of citizen has led to a generational conflict, which undermined stability. The economic growth under President Yushchenko (20042009) and President Yanukovych (2009-2014) was unsustainable because of the entanglement of economic and nepotistic power, quarrels between politicians and oligarchs and populist initiatives. Seen from this angle, the actual crisis is a late consequence of the fall of the Soviet Union. 
Typical arguments within this narrative are that a corrupt, criminal, and violent regime was replaced by a more European-minded administration after the social unrest caused by corruption and the state of the economy, sparked by the refusal to sign the EU Association Agreement (Wilson 2014, Yekelchyk 2015, Starink 2015). In a similar fashion, Western observers in the Dutch referendum campaign held that Ukraine is in an economic trouble due to corruption: non-democratic business interests, symbolized by the powerful oligarchs, have become too influential in politics (Jacobs 2016). (Other structuralist arguments are that Ukraine is prone to conflict because of internally diverging value orientations (Ryabchuk 2014) and that Ukraine is economically still very much dependent on Russia (Movcan 2015: 162).)

\subsection{International Law}

The international legal order narrative describes the Ukrainian crisis as a conflict of different interpretations of national constitutional and international law. It explains the conflict with the principle of state sovereignty and the right to self-determination, in which international law plays a pivotal role. It also proposes different interpretations of the legality of the regime change in Kiev. The conflict is centred on agreements such as the association agreement with the EU and the Budapest Memorandum. In this agreement, Ukraine accepted the dismantlement of its nuclear arsenal in exchange for recognition of its borders by the UK, US, and Russia.

Typical arguments within this narrative are that Crimea is an integral part of Ukraine, a view upheld by the EU, the USA, and most other countries in the world. Western observers hold that the return of Crimea to Russia is an attempt to reshape the international legal order, whereas Putin in his address to the State Duma on 18 March 2014 defends the right under international law of selfdetermination for Crimea (Luchterhandt 2014).

\section{Divisions in Ukrainian National Identity}

This section will treat the relations between narratives and Ukrainian national identity. All these narratives rest on opposing interpretations of various divisions in Ukrainian national identity. Karácsonyi et al. (2014) distinguish 6 divides in Ukraine: (1) ethnicity, (2) language, (3) geography (different development of steppe and forest regions and cities vs countryside), (4) history (legacies of belonging to different rulers and the interpretation of historic events), (5) politics (authoritarian/ Soviet values or Western values), and (6) religion (Kiev, Moscow patriarchate or Greek Catholic). These divisions are powerful predictors of political behaviour. 
Molchanov holds that there is not one East-West divide but that there are many linguistic, political economic, and social divides clustered together, each of them mapping onto the rest in sometimes reinforcing and sometimes unpredictable ways (Molchanov 2002: 240/280). Below, I will discuss ethnicity (3.1), language (3.2), regional differences (3.3) (which often coincide with political differences, according to Barrington-Herron 2004), and history (3.4). I will elaborate on the religious angle because the industrial East of Ukraine is not strongly religious. Where religion is more prominent, such as Crimea and Western Ukraine, it often strongly correlates with ethnicity.

\subsection{Ethnicity}

When discussing the complex ethnic character of Ukraine, reference is frequently made to Ukrainian-born Russian writer Gogol (Jansen 2014: 65, Pirie 1996: 1079). Gogol stated that he himself did not know what kind of soul he had: Russian or Ukrainian. He did not want to choose. Ironically, choosing is exactly what narratives demand from the public in Ukraine and Russia despite abundant evidence that Ukraine and Russia are close in cultural terms (Molchanov 2002: 8,226 ). I will first discuss the available data about ethnicity and then look at the interpretation of these data by the Russian and the Ukrainian camp.

\section{Ethnic Composition}

The most recent census data from 2001 show a high regional variation in ethnic affiliation. These data are based on self-identification. ${ }^{5}$ Ethnic Russians are mostly found in the five most eastern regions and, above all, in Crimea. They are also more numerous in Odessa and Kiev (see Figure 1).

The census data show a high though declining number of ethnic Russians in Ukraine between 1989 and 2001. In this period, many Russians went back to the Russian Federation because of the end of the Soviet Union. Figure 2 shows how the territory where ethnic Ukrainians live changed over time.

5 See http://www.ukrcensus.gov.ua/eng/. Due to political and methodological questions, a subsequent census was postponed until further notice. 


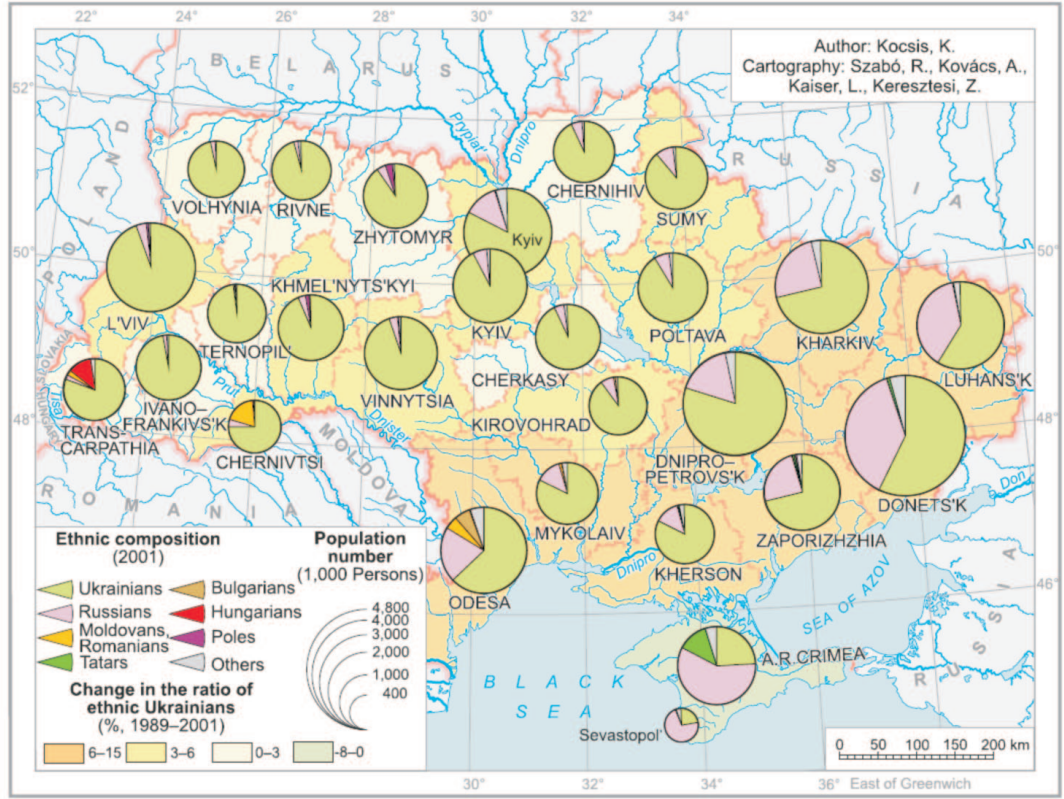

Figure 1. Ethnic composition of the population of Ukraine in 2001 (Karácsonyi et al. 2014: 115)

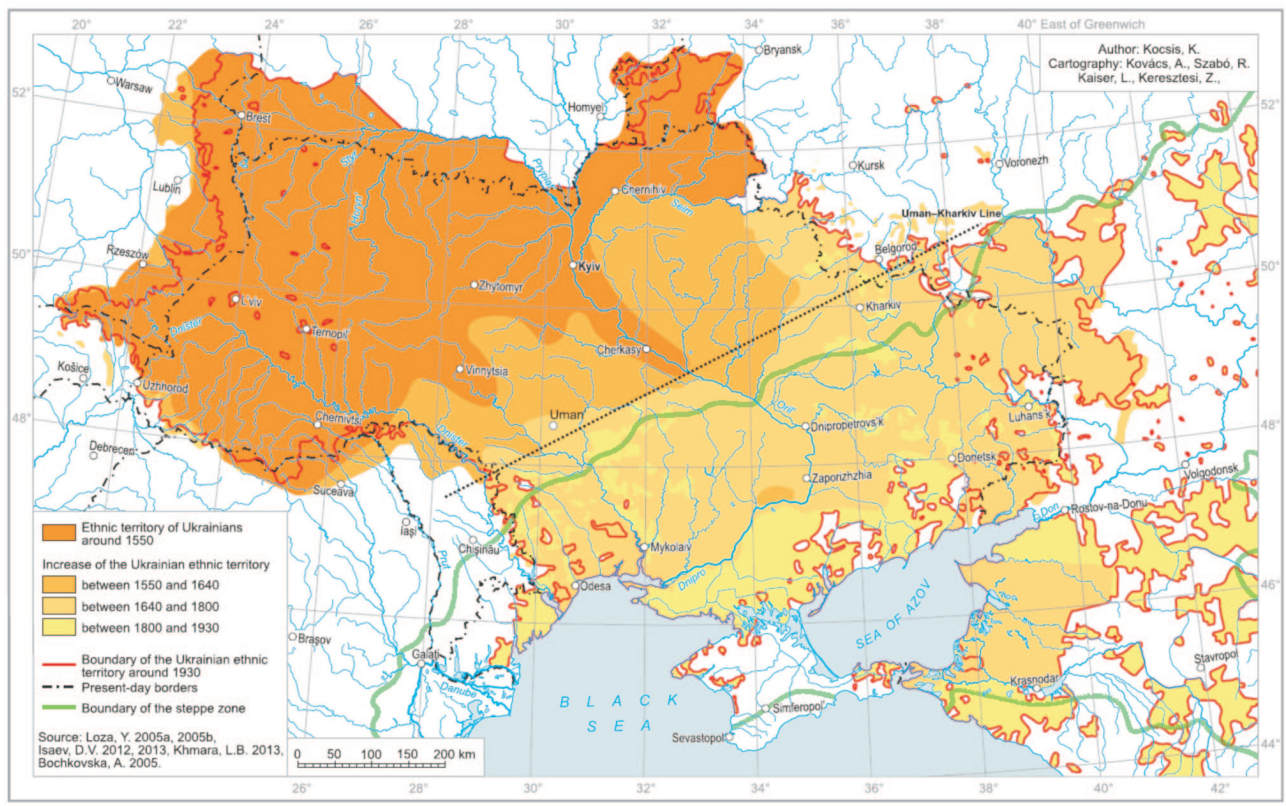

Figure 2. Change in the Ukrainian ethnic territory $-16^{\text {th }}-20^{\text {th }}$ century (Karácsonyi et al. 2014: 105) 
Ethnicity in Ukraine is not as simple as a dichotomy of Ukrainians vs Russians suggests. As census data show, a large minority in Ukraine considers itself Russian and even higher numbers of Ukrainians are Russian speaking or have Russian as their mother tongue. Pirie pointed out that categories which divide Ukraine into Russians and Ukrainians miss the point. Instead, he proposed four categories: (1) strong identification with one ethnic group, (2) strong identification with two groups simultaneously, (3) marginal identification, and (4) pan-ethnic identification (i.e. East Slav or Soviet) (Pirie 1996). His research based on sociological data revealed an important category of people with a mixed identity, which fit uneasily with the Russian nationalist narrative. His research highlighted the existence of self-declared Ukrainians communicating in Russian and (although to a much lesser extent) Russians communicating in Ukrainian. Pirie also found that, not surprisingly, Western Ukrainians show higher intolerance towards Russians than to Ukrainians (Pirie 1996: 1088). Surprisingly, on the whole, people claiming a Russian ethnicity in Ukraine demonstrate a higher level of intolerance towards Russians in Russia than they do towards Ukrainians. This finding suggests that on the whole ethnic Russians in Ukraine are marginal in their national identification.

Besters-Dilger also maintains that ethnic identities are less important than social identities (Besters-Dilger 2001: 522). Ethno-national movements are not primordialist but rather mobilizational and instrumentalist. Identities are changeable, and therefore it is premature to assume that ethnicity determines loyalty to Kiev or Moscow. Korostelina notes that the identification by the government with an ethnic or regional group has been instrumentally used by the Ukrainian government to deflect attention from economic and class issues (Korostelina 2013: 34). These nuanced views do not fit well with views expressed in more nationalist Russian and Ukrainian interpretations of ethnicity.

\section{Russian and Ukrainian Perspectives on Ethnicity}

Russian historiography (tsarist, Soviet, and post-Soviet alike) states that 'the Russian people' consist of the Russians, the Ukrainians, and the Byelorussians. Ukraine forms part of a larger Russian nation, which implies a denial of Ukrainian as a separate ethnic category (Kappeler 2011: 192). As noted by Jansen, the Soviet Union has not always been coherent in its policy towards the Ukrainian nation (Jansen 2014: 86). In the 1920s, a Ukrainian identity was promoted, whereas in the 1930s a much more repressive policy towards minorities was pursued. After the independence of Ukraine, Russian elites remained ambivalent to the degree of independence of Ukraine and Belarus (Malek 2011: 399). As a consequence, Ukraine's right to join the EU, the NATO, or even a partnership agreement is disputed with an implicit reference to the unity of the Russian people. Ukraine itself also pursued an ambiguous policy of balancing between the EU and Russia. 
When the Soviet Union ceased to exist, ethnic Russians in Ukraine showed considerable ambivalence towards the question whether Ukraine should be an independent country. Jansen argues that a reason to have voted for independence was the poor state of the Soviet economy (Jansen 2014). Pirie also interprets the 'yes' to independence in 1991 as a 'no' to the Soviet political elite in Moscow (Pirie 1996). He associates it with the widespread wish of 'becoming master in our own home' and not as a moment of national awakening of a Ukrainian identity of ethnic Russians living in Ukraine. The implications of independence were unclear to most voters. Pirie also notes that the propensity to support contradictory aims is characteristic for the Ukrainian political culture of the 1990s (Pirie 1996: 1096) and that later surveys conducted in the mid-1990s show a sharp decline in support for independence in Eastern and Southern Ukraine (Pirie 1996: 1099). Yet for all of this apparent indifference to the Ukrainian national idea, it would be equally misguided to assume the existence of a strong Russian identity in the region. The political climate of Eastern and Southern Ukraine relative to Ukrainian statehood may be best described as ambivalent: the population is attracted by both Ukraine and Russia but never fully content in its relations with either (Pirie 1996: 1099).

Although different conceptions exist (Korostelina 2013), from the Ukrainian perspective, the sovereignty of Ukraine is emphasized. Everybody with a Ukrainian passport is Ukrainian, regardless of ethnicity. The 2000s saw the advent of xenophobic and ethno-nationalist parties, such as Svoboda, with a support base in Western Ukraine. These and other signs of Ukrainian nationalism have been skilfully used by Russia to discredit the Ukrainian government and to legitimize its own initiatives in Ukraine (Wilson 2014). There are continuous accusations of payments for provocateurs to discredit Ukrainian nationalist parties. They certainly influence the climate in which radical ethnic narratives can flourish. The present conflict is rooted in ethnic tensions but does not represent a clash of two civilizations. It is rather a clash of interpretations of history and values and a sign of a deepening cultural divide between Russia and Ukraine.

\subsection{Language}

\section{The Language Situation}

In 2001, 67.5\% of the population declared Ukrainian their mother tongue. Russian is also widely spoken and understood, and $29.6 \%$ of the population declared Russian as their mother tongue, although the number of ethnic Russians is only $17 \%$. Interestingly, also $14.8 \%$ of the ethnic Ukrainians declared Russian as their native language. Moreover, about 10-15\% of the population speaks Surzhyk, a mixture of Ukrainian and Russian enjoying low prestige and spoken 
by people with a marginal national identification. Other, much smaller minority languages are Crimean Tatar, Hungarian, Bulgarian, and Romanian. Russian is most common in Crimea, Kharkiv, Luhansk, and Donetsk and to a lesser extent in Kiev and the regions in the south-east. Ukrainian is the native language of more than $90 \%$ of the population of Western Ukraine and is also widely spoken in all other regions except Crimea, Luhansk, and Donetsk, which have $25 \%$ or less Ukrainian native speakers. Of those who declared themselves Russians in those regions, 33.3\% spoke Ukrainian.

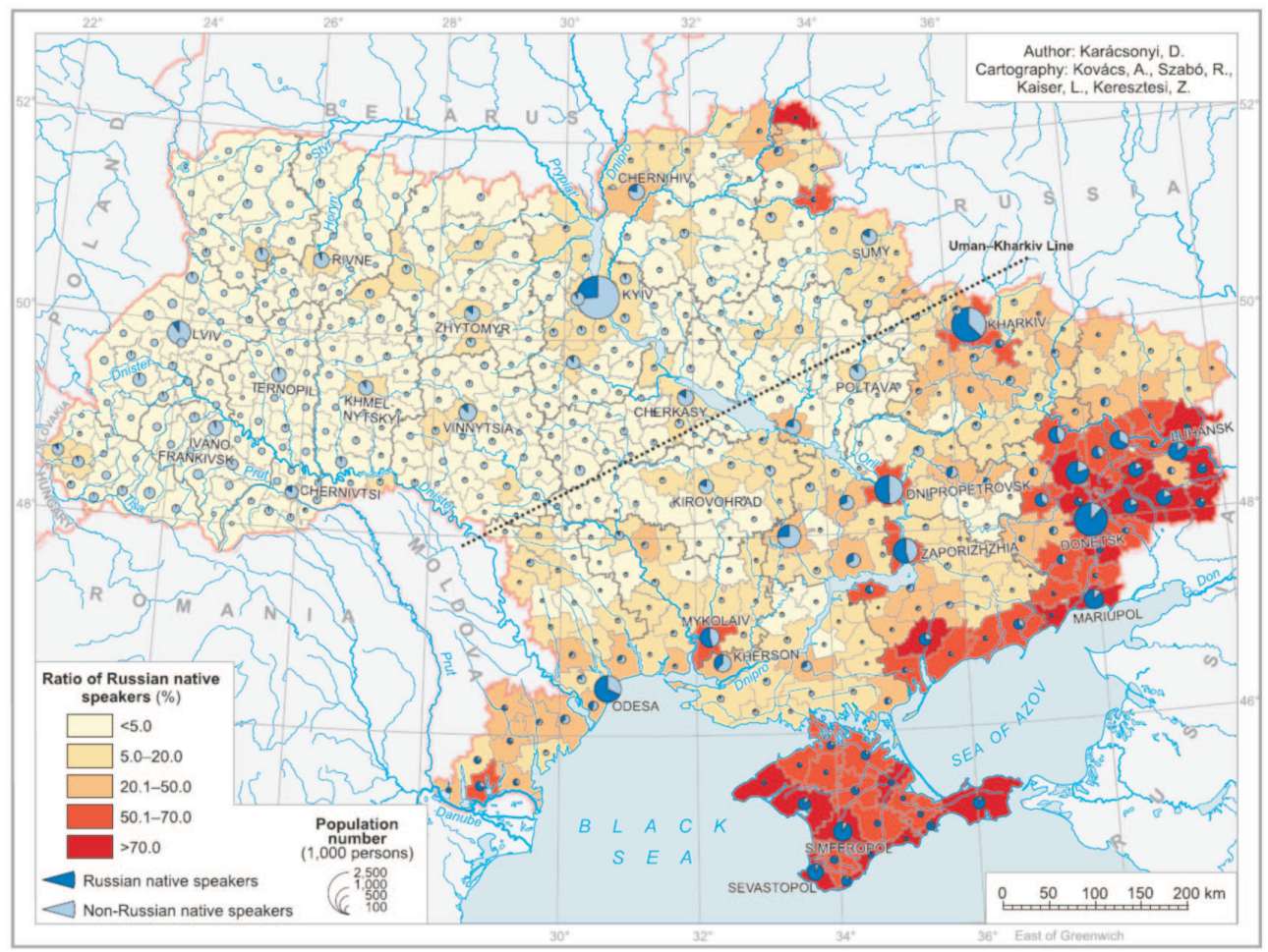

Figure 3. Russian native speakers in the districts of Ukraine, 2001 (Karácsonyi et al. 2014: 118)

East of the Uman-Kharkiv line, 50\% is Russian speaking, in Crimea, $75 \%$ is Russian speaking (Karácsonyi et al. 2014: 115). Research suggests that the number of Russophones could actually be even higher (Karácsonyi et al. 2014: 117); especially in urban areas, Russian is more widely spoken than indicated in census data. 


\section{Language Policies in Ukraine}

Ukrainian was declared the sole official language in Ukraine in as early as 1989, when Ukraine was still part of the Soviet Republic. This choice is remarkable because before 1991 Ukrainian was rarely used in public life. $51.6 \%$ of pupils were taught in Russian, not Ukrainian (Janmaat 2000). Newspapers were in Russian, and Ukrainian enjoyed a low status. Until 1989, Ukrainian was still perceived by many Russian speakers as a peasant dialect (Janmaat 2000). In 1989, Ukrainian was used for family communication, pre-school, schools (especially in Western Ukraine), certain magazines, and newspapers and in the humanities. Russian was dominant in foreign affairs and relations with other Soviet republics, economics, science, higher education (except in the fields of language and history), most of the media, and the army. Only $30 \%$ of the newspapers are Ukrainian and only $22 \%$ of the TV content on prime time (Wilson 2014: 148).

Besters-Dilger interprets the choice in 1989 for Ukrainian as the only state language as a strategic move to increase the use and status of Ukrainian (BestersDilger 2001). Concomitantly, Russian was designated as the language for interethnic communication. Enforcement of the use of Ukrainian was not too effective, and some cities, such as Odessa and Donetsk, declared Russian as the second official language. Crimea adopted Crimean Tatar and Russian besides Ukrainian as their official languages. When Ukraine became independent in 1991, Ukrainian was re-affirmed as the sole official language, with an exception made for Donetsk. This gave Ukrainian another boost.

During the 1990s, a policy of promoting the use and prestige of Ukrainian was pursued, most effectively in education. New language laws were introduced. The constitution was not altered, but it promulgated Ukrainian as the state language of the government unless there was a regional Russian-speaking majority and the government decided that government communication could also take place in Russian. The 1996 Constitution officially confirmed that education in Russian was possible. Measures to promote the use of Ukrainian included quota for Ukrainian language use in the media, use of Ukrainian in education, and the provision of general support for efforts to research and expand (the use of) Ukrainian. This policy was felt as discriminatory by Russian-speaking Ukrainians and Russians in Ukraine, even though Russian could be taught as a minority language and retained official status in Crimea. In the media, Russian still dominated the newspapers in the second half of the 1990s. However, after the turn of the century, the majority of the TV programmes switched to Ukrainian.

The status of Ukrainian as the nation-state language was confirmed by the Language Law of 2012, which formally introduced regional languages for national minorities. According to a survey conducted together with the Kiev International Institute of Sociology, an estimated 59\% of the Maidan protesters spoke Ukrainian, 
while $24 \%$ were bilingual. Contrary to common assumptions about an East-West divide (with the East supporting Russia), 21\% of the protestors came from Eastern Ukraine (Karácsonyi et al. 2014: 125). Wilson quotes a poll showing that 4 to $24 \%$ of the Russian speakers perceived a threat to Russian language rights when the Maidan protests started (Wilson 2014: 150).

\section{Perspectives on the Use of Ukrainian}

Besters-Dilger distinguishes four positions of Russian speakers towards the use of Ukrainian language: (1) discrimination and betrayal of the positive Russian role and the common heritage, ${ }^{6}$ (2) Ukrainian is not important because it is culturally less developed than Russian. More radical commentators still hold that Ukrainian is not a language but merely a Russian dialect, (3) propagating Ukrainian is seen as an instrument of Western Ukrainians to take over important positions, and (4) Ukrainian is an instrument of foreign powers aimed at weakening and ultimately destroying the Russian unity (Besters-Dilger 2001).

Ironically, communists were not reluctant to promote Ukrainian language and culture if it suited their aims or fitted in the Zeitgeist. A particularly strong example is the Ukrainization policy of 'korenizatsiya' (literally 'indigenization') pursued by the Soviets until the early 1930s. This policy consisted of promoting the languages of each Soviet minority and giving positions in the party to local communists. Subtelny (2011) and Magocsi (1996) pointed out that even in czarist times, the University of Kharkiv was a hotspot of Ukrainian nationalists. Ironically, their aims were realized by Soviet bureaucracy in the late 1920s, when impressive figures for the use of Ukrainian were reached in what is now Eastern Ukraine, and over $70 \%$ of the Ukrainian SSR (roughly Southern and Eastern Ukraine without Crimea) became Ukrainian speaking (Karácsonyi et al. 2014: 110).

This all ended in the 1930s, when new steps were taken in the collectivization of the agricultural sector. The use of Ukrainian deliberately became synonymous with suspicious activities and was associated with kulak farmers. With the advent of Stalinism, the strengthening of the Russian element in Ukraine became more and more important. The status of Ukrainian dwindled and continued to fall until the death of Stalin in 1953. In the Khrushchev era, the Communist Party in Ukraine introduced measures to stimulate Ukrainian. These were later reversed in the Brezhnev era. Only with the Fall of Communism and perestroika did the use of Ukrainian regain priority.

The diminishing use of Ukrainian in the Soviet Union does not imply that Russophone Ukrainians have actually dropped their Ukrainian identity (Janmaat

6 In the 1990s, protest were voiced against the reduction of the use of Russian, among others, by Solzhenitsyn (who also propagated the reunification of eastern Ukraine with Russia) (Kohut 2011: 239). 
2000: 35). They prefer good relations with Russia and at the same time consider themselves different from Russia (Jahn 2015: 43). Conversely, the willingness to speak Ukrainian correlates with support for the Ukrainian state. Obstruction to linguistic Ukrainization is mostly found in the East because in this case a lowstatus language was introduced in an area where Russian enjoyed high status.

From a Ukrainian point of view, the ability to speak Ukrainian is required, and the use of Ukrainian should be promoted and policies formulated accordingly. Positions towards the use of Russian differ from tolerant - as long as they are loyal Ukrainians - to hostile. In the latter case, every concession to the use of Russian is seen by Ukrainian nationalists as a step in the Russification process. On the other hand, Molchanov cites polls indicating that $70 \%$ of the Ukrainians favour some official status for the Russian language (Molchanov 2002: 226). Janmaat (2000) established a correlation between political preference for Kuchma and Russian speakers but notes that it has diminished during his presidency. Political ideology and generational effects seem to be more important divisions than language. For instance, a Russian-speaking city like Kharkiv can easily be (Onwijn 2005) mistaken for a Russian city, whereas the recent events have proved that the fact that most inhabitants have Russian as their first language was not enough reason to side with the separatists. It is therefore the failure to depoliticize the language issue that leads to political instability, not the linguistic distribution in itself.

\subsection{Interpretation of History}

Both the Ukrainian and the Russian version of the nationalist narrative rely heavily on the interpretation of key historical events since adherents of these narratives believe that the right interpretation of history is a guarantee for the future (Velychenko 2000, Sheiko-Brown 2014). In their view, the basis of local statehood has to be justified by history. Statehood is rootless without blood and soil arguments (Wilson 2014: 11). Today it is believed by the Kremlin that history determines the future, which justifies rewriting history along patriotic lines. Authoritarian patriotism is embraced by the leading political parties. It is also needed to justify the role of post-communist Russia. Unlike in the West, where China or the Arab world is the other, in the state-authorized Russian interpretation of history, the West constitutes the 'other'. Russia, and to a lesser extent Ukraine, have both actively sponsored grand schemes explaining the past and giving directions for the political course of the country.

The Russian perspective on these events is influenced by identity debates in Russia, which followed the identity crisis after the collapse of the Soviet Union in 1991. These debates can be seen as a revival of the debate between Westerners and Slavophiles in the $19^{\text {th }}$ century, with a variation on the arguments 
of an enlightened and modern West and spiritual and traditional East. In these discussions, Eurasianism is a recurring feature. Sheiko and Brown define Eurasianism as a broad spectrum of views united by a preference for the spiritual and collective East as opposed to the mechanistic and individualistic EuroAmerican world of the West (Sheiko-Brown 2014: 60).

The 1990s and especially the beginning of the $21^{\text {st }}$ century saw the advent of radical interpretations. It is not uncommon to state that enemies aim to disempower Russia by depriving it of its true past. An exemplary and influential thinker is Anatoly Fomenko, author of New Chronology, which inspired a movement to revise history (Sheiko-Brown 2014: 14). Fomenko moves between conspiracy theory and rewriting history. His aim is to show how powerful, virtuous, and remarkable Russia has been and how it has been repressed by others. It is therefore important to rewrite history along patriotic lines to avoid events that led to the collapse of Russia in 1917 and 1989. Russia is neither European nor Asian and itself not repressive. Ukraine and Russia have no identity outside of their mutual connection. Ukrainian history is seen as provincial Russian history. Interestingly, a similar view, albeit with a different motivation, was upheld by traditional Polish historiography, which saw Ukrainian history as the history of rebellious peasants.

In Ukraine, national identity is also hotly debated as Ukraine faces the same postSoviet identity crisis. Ukrainian historiography opposes Russian historiography by arguing that there is continuity between Kievan Rus', the Cossack state of the $17^{\text {th }}$ century, and present-day Ukraine. It claims that the Ukrainian nation has existed throughout history and that it deserves its own independent state and language. The first purpose of Ukrainian historiographers was to have Ukrainian historiography within a meta-Russian nationality and state. At the end of the $19^{\text {th }}$ century, a completely separate history emerged (Kohut 2011: 216). The most frequently used events and episodes, Kievan Rus', the Treaty of Pereyaslav, World War II, and the fall of the Soviet Union will be discussed to show how different interpretations of history look like and how they influence the understanding of Ukrainian politics (Golczewski 2011: 319).

The Historical Development after the Fall of Kievan Rus', Pereyaslav, and the Cossack State

There is considerable historiographical controversy about whether Kievan Rus' gradually moved to Moscow or whether various civilizations sprang from the cradle of Kievan Rus' (Subtelny 2011: 20). In the Russian nationalist narrative, the Karamzin conception of history is hegemonic. Here, there is a transition of centres ending in Moscow and only one Russian people, leading to the thesis of the unity of the 'Rus people' (Kohut 2011: 1/187, Subtelny 2011: 22). Subdivisions between 'Great Russians' and 'Little Russians' are possible but do not imply 
recognition of a degree of difference that justifies independent statehood. The prestige and legitimacy of Moscow is further reinforced by the connection with Orthodoxy as the Third Rome and seat of the Metropolitan, later Patriarch of the Russian Orthodox Church. Dynastic, religious, imperial, and historical elements are combined to present one primordialist grand narrative of 1000 years of Russia (Portnov 2011: 30). In this narrative, Ukrainian distinctiveness in speech and customs is explained by Polish influences.

A rival interpretation was proposed in the $19^{\text {th }}$ century by the famous Ukrainian historian, Hrushevskyi, who contended continuity between Kievan Rus' and the principalities of Volynia and Galicia (Polonska-Vasylenko 1968, Velychenko 1992, Magocsi 1996, Snyder 2003). He argues that there are three branches which descend from Kievan Rus': the Russians, the Ukrainians, and the Byelorussians. Besides cultural distinctions, this approach also allows for politically different courses of the present countries: Ukraine, Belarus, and Russia. In this view, Ukrainian entities were driven to alliances with Poland and later Russia.

The implications of both theories are far-reaching. In the so-called Karamzin conception of history, there is no place for an independent Ukraine. The alternative Hrushevskyi thesis leaves ground for radical nationalist interpretations, which would sit awkwardly in a country which not so long ago was one with Russia and which is culturally and economically closely knit to Russia. In either case, one country had to give up the beginning of its history to the other: the heritage of Kievan Rus'.

The Treaty of Pereyaslav (1654) is a significant moment in the history of Ukraine and Russia because it has been interpreted as the union between the Ukrainian and Russian people. In this ambiguous treaty, one of the most revered Ukrainian Cossack leaders, Bogdan Khmelnitsky, pledged adherence to the Russian tsar. From the Russian point of view, this was an irreversible subordination of Ukraine to Russia (Kohut 2011: 15). It is often ignored that just ten years later the Ukrainians concluded a similar treaty with the Poles in order to secure their support. The Ukrainian nobility believed in a contractual relation with the tsar following the model of Polish szlachta and the Polish king. This idea was not shared by the tsar or the Russian administration (Kohut 2011: 87).

The Treaty of Pereyaslav could also be seen as one in a sequence of treaties and agreements which Cossack leaders concluded with varying foreign powers, thereby switching alliances when they deemed it expedient. The Ukrainians turned to the tsar because they were disappointed by the limited progress that the king of Poland had made in granting the same rights to the Ukrainian nobility as he had granted to Polish nobility, a situation mirrored by the relations between Ukraine and the EU. In the latter case, Ukraine turned to the party with the most attractive offer. From the Ukrainian point of view, the Treaty of Pereyaslav was a union recognizing the rights and privileges of Ukraine and not an unconditional union with Russia. 
A crucial link in Ukrainian historiography is attributed to the Cossack state of Hetman Bohdan Khmelnytsky in the seventeenth century. Under his leadership, the Cossack state reached its zenith in terms of territory, in terms of privileges from Poland and Russia, and military power. Freedom was believed to be almost boundless, in strong contrast to autocratic tendencies in Russia. Ironically, Cossack mythology is popular among the nationally conscious in Western Ukraine, although it is historically rooted in Left-Bank Ukraine and cannot be purged from Cossack collaboration with the Russian empire (Molchanov 2002: 241).

With the incorporation of the Cossack state into Russia in the $18^{\text {th }}$ century, the term Little Russia emerged. The original political entity was diluted by a gradual strengthening of Russian administrative structures. Political distinctiveness decreased and was over at the end of the $18^{\text {th }}$ century when the Hetmanate was abolished (Kohut 2011: 33). The elite integrated in the Russian nobility and became more oriented towards Russia. Russian identity proved more attractive than the Ukrainian one because it was based on the language and culture of their serfs in Ukraine (Kohut 2011: 56). Interpretations started to diverge again in the first quarter of the $19^{\text {th }}$ century.

\section{Contentious Historical Figures}

In the nationalist narratives, both sides make frequent references to contentious figures such as Ivan Mazepa (1639-1709), Joseph Stalin (1878-1953), and Stepan Bandera (1909-1959). It is insightful to consider them because they still cause considerable controversy. In the Russian point of view, Ukrainian nationalists are traitors of the worst kind of the pan-Slavic idea and marionettes of foreign powers (Kappeler 2011: 194). On the other hand, Russian rulers are portrayed as undemocratic and aggressive. The common feature is that all these historical figures wanted to break or reinforce the political ties between Ukraine and Russia. Because they are all part of Russian and Ukrainian history, it is hard to combine for instance a hero status for both the Red Army and the UPA (Ukrainian Insurgent Army) in one historical consciousness.

Where the overall assessment of Stalin is not purely negative in Russia, it is considerably more negative in most parts of Ukraine because of Stalin's role in the Holodomor and his oppression of Ukrainian nationalist movements.

Hetman Ivan Mazepa led an attempt to side with Sweden against Tsar Peter in defence of Ukrainian interests and has been portrayed as a traitor of the Russian cause. On the other hand, he is portrayed in Ukrainian history as a defender of Ukrainian freedom against interference from Moscow.

Probably the most contentious person in modern Ukrainian history is Stepan Bandera, often labelled as fascist or neo-fascist (Onwijn 2005: 51). Although arrested as early as June 1941, he became the symbol of the Organization of 
Ukrainian Nationalists (OUN) and the UPA, founded by the OUN. Bandera inspired the more revolutionary branch of the OUN, which later split in two factions: the OUN-B(andera) and OUN-M, named after Melnyk, who was a more moderate Ukrainian nationalist. The UPA was an underground Ukrainian army under the Banderite faction which fought against Germans, Poles, Jews, and Russians. Throughout the war, the OUN remained internally divided about the cooperation with the Nazis in order to establish a Ukrainian state or to fight the Soviet Union, although, at least initially, the Germans were welcomed as liberators in Western Ukraine.

\section{World War II and the OUN/UPA}

In order to understand the Russian narrative of 'fascist Ukraine' and the Ukrainian nationalist narrative of 'defending the right cause', I will examine the role of Ukrainian nationalists in WWII. Ukrainian nationalists in the Ukrainian lands under Polish rule had been waiting for their chance to establish an independent state. With the advance of the Nazis in 1941, the OUN believed this chance had come. The OUN welcomed the Nazis and hoped to get support for setting up their own state just like the Slovaks and the Croatians had done. They knew they had little to gain from the Poles (who had always been their masters) or the Russians (who organized mass starvation to wipe out class enemies in the Ukrainian Soviet Republic). On 30 June 1941, independence was declared. The German attitude to the OUN was ambivalent (Golczewski 2011: 330). Military circles were not entirely deaf to the option of working with the Ukrainians, but Hitler declined that option. As a consequence, Ukraine suffered the same fate as many other territories in the newly acquired 'Ostland' because Germany was mainly interested in using Ukrainians as a workforce for its war effort against Russia. There were several attempts to recruit Ukrainians to fight the Soviet Union (see Table 1).

Although it is clear that some Ukrainians collaborated with the Germans and had strategic reasons for doing so, it remains open for discussion whether the percentage of Ukrainian collaborators was higher than in other countries or parts of the Soviet Union. The example of the Russian Liberation Army under Vlasov shows that Russians could also be mobilized to oppose the Soviet Union. Nevertheless, in the Russian nationalist narrative, Ukrainians are depicted as collaborators, whereas Russian collaboration did not take place despite abundant evidence to the contrary. 
Table 1. Summary of Ukrainian war efforts for Nazi Germany (Golczewski 2011, Boshyk 1986, Hausmann \& Penter 2014: 41)7

\begin{tabular}{|c|c|c|c|c|c|}
\hline Year & Name & $\begin{array}{l}\text { Political } \\
\text { agreement }\end{array}$ & Support & Number & Actual involvement \\
\hline 1941 & Roland/Nachtigall & Yes & OUN-B & $600-800$ & $\begin{array}{l}\text { Advance in Ukraine } \\
\text { and Bessarabia in } \\
\text { 1941, combat Soviet } \\
\text { partisans in Belarus }\end{array}$ \\
\hline 1943 & $\begin{array}{l}\text { SS Division } \\
\text { Galicia and its } \\
\text { successor, the } \\
1^{\text {st }} \text { Ukrainian } \\
\text { division. }\end{array}$ & Yes & $\begin{array}{l}\text { OUN-M, Ukrainian } \\
\text { Central Committee } \\
\text { presided by } \\
\text { Kubiiyovich, } \\
\text { sheptyts'kyi } \\
\text { Against: OUN-B, UPA }\end{array}$ & $13,000^{7}$ & $\begin{array}{l}\text { Against the advance } \\
\text { of the Red Army, } \\
\text { combat partisans in } \\
\text { Slovakia }\end{array}$ \\
\hline $\begin{array}{l}1941- \\
1945\end{array}$ & $\begin{array}{l}\text { Various smaller } \\
\text { units of Red Army } \\
\text { prisoners and } \\
\text { forced labourers }\end{array}$ & No & N/A & $\begin{array}{l}\text { Estimate } \\
10,000\end{array}$ & \\
\hline
\end{tabular}

Whereas Russia argues that it is the biggest victim of World War II, a case could be made for the opposite position: not Russia but Ukraine suffered the most. In support of this claim, it is argued that World War II was fought to a larger extent on Ukrainian territory rather than on Russian territory. Warfare on Ukrainian territory resulted in a considerable number of casualties who fell in the 'bloodlands' (Snyder 2010: 10), who were more often Ukrainians (Jansen 2014: 139) or other non-ethnic Russian nationalities than Russians (Wilson 2014: 72).

Another argument supporting the 'Ukraine as victim' thesis is provided by the abundant evidence of the representation of Ukrainians in the Red Army (Potichnyj 1986, Snyder qtd in Starink 2015: 250). The suffering of the Ukrainian population and the efforts of soldiers from Ukraine are downplayed by Russia, who claims to be a victim of the Nazis and the heir of the heroic struggle against the Nazis, not Ukraine. In this discourse, the collaboration of some Ukrainian nationalists is highlighted, while leaving out their war efforts against the Germans and the Poles, who were also unwilling to create an independent Ukraine (Yurkevich 1986: 73). The fact that UPA longed for independence and would collaborate with any party helping them to realize this is overshadowed by its radical right ideology and violent practices. This brought it ideologically closer to the Nazis than to the communists or the political systems of neighbouring states in central Europe. Potichnyj argues that UPA was composed of all kind of nationalists and that it was oriented towards the Italian model (Potichnyj 1986: 65). The degree of violence used by the UPA did not differ significantly from that used by other forces at that time. In the Russian view, Bandera is a fascist, a label applied to anybody who is an existential threat to Russia (Wilson 2014: 125). As long as

7 80,000 Ukrainians volunteered, only 8,000 were selected (Rossolinski-Liebe 2015: 255). 
Stalinism is presented as progress in Russia, and the suffering it caused neglected, Ukraine ignores what Russia says about Bandera.

\subsection{Regional Identities}

The divides in Ukraine's national identity discussed above are mirrored in the regions of Ukraine, which each have very different histories and social economic characteristics. Ukraine exhibits a multilevel regional structure formed in the course of a long historical development reflecting the nation-forming attitudes of Ukrainians. In 1991, for the first time in history, these regions formed an independent state under one administration. This regional variety complicates national consolidation and continues to influence daily life (Molchanov 2002: 239). Regional and historical legacies complicate the process of nation-building and make Ukraine especially vulnerable to external (EU, Russia) and internal (oligarchs) interventions. I will therefore describe the regional differences.

\section{The North, West, and Centre}

The west of Ukraine consists of territories that shared two characteristics: they were for long periods in history part of other empires or states and did not belong to the Soviet Union either before 1941. The centre and the north were largely part of the Soviet Union but also historically part of all pre-modern Ukrainian political entities such as Kievan Rus' and the Cossack state. The figures below depict the political entities on the territory of present-day Ukraine. The Cossacks were active in most of the centre, south, and east but not in the west.

Following Barrington and Herron, the northern, central, and western parts can be further divided into the south-western regions, which prior to 1940 belonged to Czechoslovakia (Zakarpattya) and Romania (Northern Bukovina), and the west (Galicia) and west-central regions (Podillya and Volynia, which belonged to the Kingdom of Poland) (Barrington-Herron 2004). Before 1920, most of these territories were part of the Austrian-Hungarian Empire and some of the Russian Empire (after the partitions of Poland). Prior to 1795, most of the territories on the right bank of the Dnepr belonged to Poland. These western parts are the least Russified (Karácsonyi 2014: 111, Jansen 2014: 152). World War II touched all regions, although most battles were fought in the East of Ukraine.

The following figures show the states on the territory of present-day Ukraine. 

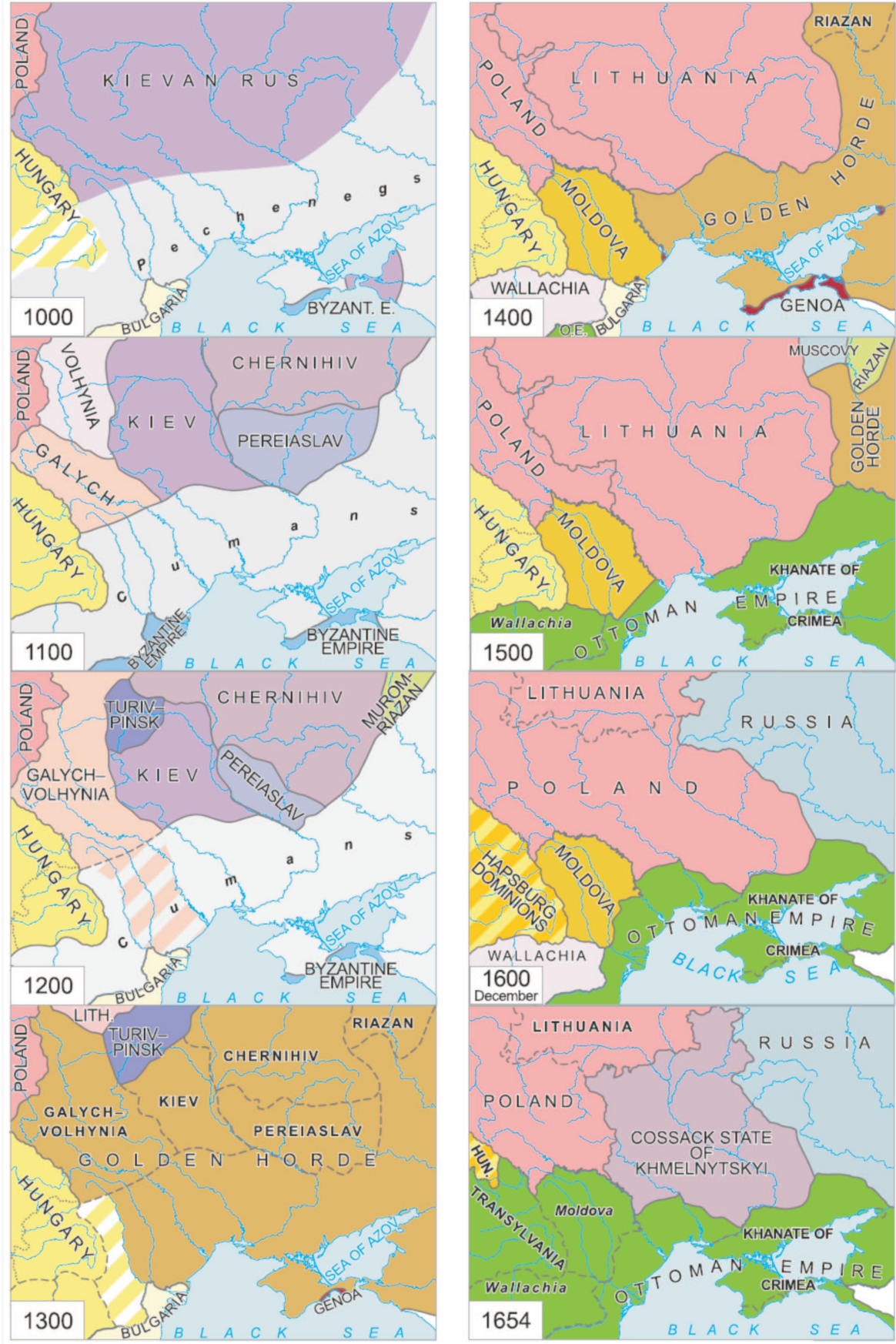

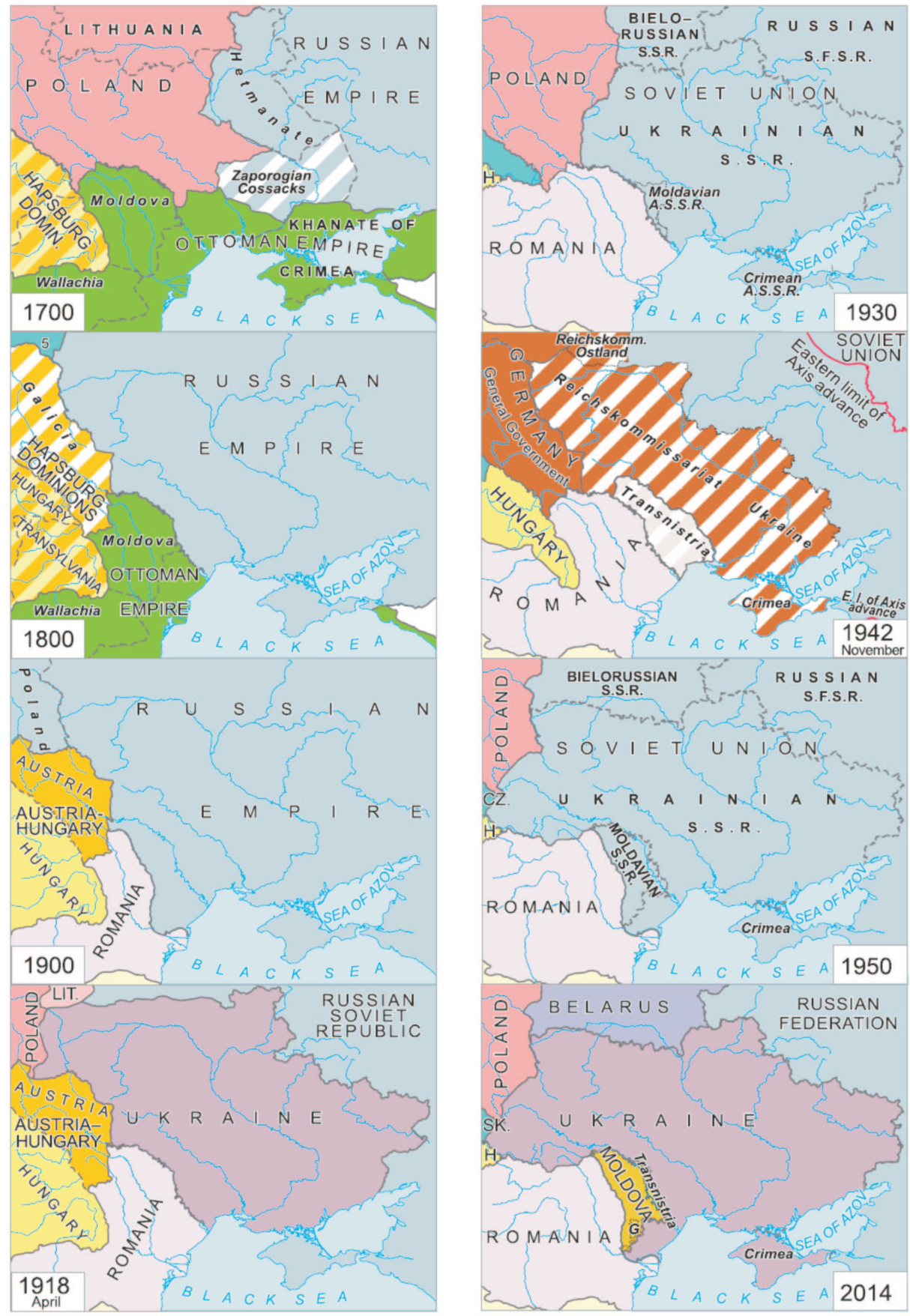

Figures 4 and 5. States on the present territory of Ukraine: 1000-1654 and 1700-2014 (Karácsonyi et al. 2014: 106-107) 


\section{The South and East}

Southern and Eastern Ukraine, the so-called 'wild fields' (Polish: Dzikie Pola), were largely uninhabited. These territories could not be efficiently controlled by Slav rulers and were partly cultivated by Cossacks during peace time. For a long time, the territory belonged to the Mongol empire of the Golden Horde and later to the Crimean Khanate (the Tatars), which frequently organized raids into the wild fields. The area was first colonized after the advance of Empress Catherina at the end of the $18^{\text {th }}$ century. As the newly conquered territories had to be colonized, Donetsk was founded in the late $19^{\text {th }}$ century, and the region changed character under the influence of industrialization and the influx of immigrants from all parts of the Russian Empire. The population increased five- to ninefold between 1810 and 1910, and the region was commonly denominated as New Russia (Novorossia), designating the provinces bordering the Black Sea but not Kharkiv. At present, the eastern parts of this area are among the most urbanized areas of Ukraine after Kiev. Already in 1897, all major cities had a Russian majority thanks to industrialization. Still, ethnic Russians mainly live in the industrialized cities of the East. In rural areas, their numbers have decreased. Interestingly, the Uman-Kharkiv line corresponds to what historically was called Novorossia, with the notable exception of Kharkiv. Historically, cities were less Ukrainian than the countryside. Bigger cites tended to be inhabited by Poles and Jews in the West and Russian-speaking migrants in the East. Today, the bigger cities in Ukraine, especially the industrialized cities in the East, show higher numbers of ethnic Russians and Russian speakers. It is among this group of Russian speakers living in cities that support for Yanukovych was the highest (Karácsonyi et al. 2014: 123). The correlation between Russian ethnicity and the votes for Yanukovych is lower because Russians in rural areas were less inclined to vote for Yanukovych. This shows that support for Yanukovych is not purely organized along ethnic lines. His more permissive stance on the language issue also persuaded Transcarpathians - many of whom understand at least some Hungarian or Romanian - to give him their vote in 2010. The Russian-founded city of Odessa shares linguistic characteristics with cities in the East, which are also inhabited by Russian settlers and migrants, such as Donetsk. It is also a very mixed city with various nationalities, including a fair share of ethnic Russians.

The easternmost regions bordering Russia are Luhansk and Donetsk. Historically, these lands were not a part of Kievan Rus' or the Cossack state. They were sparsely populated and since the year 1000 for most of the time in the hands of Tatars. An important difference between Eastern and Western Ukraine is that the eastern regions which belonged to the USSR experienced the Holodomor (1932-1933), while the western regions did not. The Holodomor enabled further Russification of the eastern regions, which were repopulated by settlers from other parts of the Russian empire. 
Regarding Luhansk, Donetsk, Kharkiv, and the South-East, pleas for a federal structure were very common after 1991. The term 'Novorossiya' was already voiced in 1991 in the southern oblasts. In 1994, a referendum was held in Luhansk and Donetsk, which led to the introduction of Russian as a language of administration. Of the southern and eastern oblasts, Kharkiv and Dnipropetrovsk are much more linked to central Ukraine. In contrast to these cities, Donbas possesses a stronger local identity.

In Donbass, the national identification is more mixed through intermarriage and migration from Russia. There has been continued support for close ties with Russia and the former Soviet Union despite increasing cash flows from Kiev flowing to Donbass and not the other way round (Wilson 2014: 122). Support for closer ties with Russia has never been sufficiently strong to sustain a fullfledged movement for the reintegration of Ukraine into Russia, as support for such an idea is likely to be as unreliable and ambivalent as support for Ukrainian independence has been (Pirie 1996: 1100).

\section{Crimea}

A special situation exists in Crimea, where, according to some observers, already in the 1990s, a majority of the population wanted to belong to Russia (JordanMunz Ohliger 1999: 20). Arguably, Crimea has shown the most signs of unease about being part of Ukraine. Crimea was a Russian elite destination and Sevastopol the cornerstone of all Russian claims to Crimea although it became part of the Russian empire only in 1783, after the defeat of the last khan by Catherine the Great. Crimea is not only the basis of the Black Sea fleet and a holy ground in the national psyche because of the Crimean war and WWII (with heroic defeats in 1853 and 1941) but it has also spiritual significance (Putin in his reunification speech, 4 December 2014). Allegedly, Kiev Prince Vladimir the Holy (988-1015) was baptized here, thus introducing Christianity in Kievan Rus'. In Crimea, the Russian population has maintained a strong attachment to the Russian Orthodox Church, which is an important symbol of Russian national identity (Pirie 1996: 1089). Another explanation for the Russian interest in Crimea is that many ethnic Russians in Crimea were born in Russia.

The years 1990-1994 saw a rush for Crimean separatism, and Crimea even declared independence as early as 1992, which was reversed by the skilful diplomacy of President Kuchma and the granting of more autonomy. Sasse cites four reasons why the Crimean question did not lead to a conflict. She points to the multiethnic character of Crimea (Sasse 2007: 8). Then, the Russian movement in the 1990s was ineffective because it could not combine ethnopolitical mobilization with a socioeconomic delivery (Sasse 2007: 254). Russian nationalism, incapable of addressing needs or resenting a clear identity or 
common objective, pragmatic concerns about bread and butter issues, prevailed over identities. Jordan explains the calming down of nationalist ambitions by a conciliatory approach in Kiev and lack of support by Russia in the Yeltsin era. He also points to the Ukrainian-Russian Friendship Treaty of 1997, in which the territorial integrity of Ukraine was guaranteed. Furthermore, internal rivalries and the dire economic situation in Russia prevented a more adventurous Russian approach of Crimea. He concludes that these parts of Ukraine cannot be governed without the support of ethnic Russians living there.

The pragmatic approach of Kiev and the absence of real Russian support were key to conflict prevention in the 1990s. Still, according to Sasse, Crimeans (both Russians and Ukrainians) have been in favour of improved links or integration with Russia. Jordan cites research from Münz and Ohliger, stating that 90\% of the Crimeans still wanted a union with Russia after the Treaty (Jordan 1999: 81). As for ethno-political mobilization, the historical animosities between Russian and Crimean Tatars were more pronounced than between Russians and Ukrainians in Crimea. Mobilization was against Ukrainians in Kiev with a nationalist agenda, not against Russophone Ukrainians in Crimea.

In 2014, Russia under Putin succeeded to reverse all of the reasons found by Sasse. Ukrainians could be blamed because of the regime change in Kiev, that delivery of essential services seemed to be better than under the dysfunctional Ukrainian economy, and external support of Russia was well provided. Most decisively, no real effort was made from Kiev to reverse the Russian takeover of Crimea. Pirie's prediction that viable pro-Russian separatism is limited to Crimea became reality (Pirie 1994: 1099-1100). Nevertheless, Sasse's findings raise questions about the sustainability of the Russian arrangement in Crimea once delivery is flawed and the degree of autonomy from the centre (Moscow instead of Kiev) turns out to be diminished.

\section{An East-West Divide?}

Various attempts have been made to draw divisions along regional lines. The most commonly used distinction is between Eastern and Western Ukraine. As Karácsonyi et al. showed, an east-west dichotomy is too simple (Karácsonyi et al. 2014, Barrington-Herron 2004). Ukraine's east-west divide does not stem from a conflict between ethnic Russians and ethnic Ukrainians. In order to make more meaningful contentions about Ukraine, Karácsonyi proposed the Uman-Kharkiv line (Karácsonyi et al. 2014). This line can explain why the Ukrainian nationalist narrative is strong in Western Ukraine and the Soviet legacy in the East and why the South ('Novorossia'), East, and Crimea are so prominent in Russian narratives. 


\section{Diverging Political Values after 1991?}

The 1990s were a period of disorder and instability in Russia and Ukraine. Although the fall of the Soviet Union left both countries in a similar position, with similar economic experiences, they developed different attitudes towards the fall of the Soviet Union and different value orientations, with the picture differing strongly within Ukraine. In parts of Southern and Eastern Ukraine and especially in Crimea, Soviet-style values prevailed. Economic and political paternalism at the top level of state bureaucracy, state companies, and private sector managers is very strong. Most workers are politically in a state of infancy and crave for a strong state with strong leaders and state welfare (Korostelina 2013: 35, 38), family values, submission to a strong state, hierarchical and administrative management, and paternalistic expectations of welfare. The dominance of Russian, the influence of Moscow is accepted in a kind of post-colonial relation. Many elements of the Soviet way of arguing, such as 'Russia against the West', which also has its weaknesses, and the WWII glorification fit very well in this value system. Nevertheless, these values and orientations are gradually losing strength on an East-West scale.

After becoming president for the third time in 2012, Putin presented Russia as 'the guardian of older and truer European values, the Holy Trinity of God, authority, and family; essentially, a conservative values project' (Wilson 2014: 3). Russia adopted the communist propaganda version of capitalism and entered an ultra-cynical world of manipulation where everything is permissible and where there is no truth. In this world, political technologists create a fake democracy based on informal networks and backroom politics, using agents, provocateurs, compromising material, and bribery with modern capacities such as social media, blogs, trolls, and web brigades, which have provided scripts that everyone had to follow (Wilson 2014: 21-23). NGOs and political parties can be manipulated at will to disguise the weaknesses of the system such as corruption (Pomerantsev 2015). Institutions are kept weak so that political technology can do its work (Wilson 2014: 25).

On the other hand, in the former Polish, Czechoslovak, and Romanian areas which belonged to the Soviet Union, a post-Soviet (not necessarily pro-western or liberal) orientation exists among the cultural, political, and economic elite of Ukraine. These areas are more oriented towards central Europe and show a desire to take the path of Poland and the Baltic states (Ryabchuk 2011: 427). A similar desire for political and individual development, albeit less nationalistic, is felt in central Ukraine and in most big cities. Corruption is deemed unacceptable and spheres of influence and 'legitimate interference' by Russia in Ukrainian affairs are denounced. Putin is aware that this change in mentality in the most important former Soviet republic is an existential threat to his political system. 
The process of change in political values in Ukraine rests on a critical rethinking of the Soviet past, and it is still ambiguous. Many Ukrainian political observers complain that the majority of the population behaves post-colonial, is denationalized and materialistic. This socio-cultural divide has become a major source of conflict. The positive approach of President Yushchenko (2004-2009) to Holodomor and the re-appreciation of the OUN (Organization of Ukrainian Nationalists) did not receive support in Eastern Ukraine and led to ethno-cultural tensions (Korostelina 2013: 41). Kuchma and Yanukovych promoted the Soviet idea of power because it gave them a source of legitimacy, fulfilling the needs of those who were, more or less, still homo sovieticus. This internal orientation did not prevent them from pursuing a multi-vectored, balanced foreign policy when dealing with the West.

\section{Conclusions}

This working paper presented four overarching narratives comprising the arguments put forward during the Ukrainian crisis. These narratives are: nationalism, geopolitics, structuralism, and international legal order.

These narratives provide the framework for most of the contentions of both sides in the Ukrainian crisis. These narratives are represented in the following diagram. Examples of the contentions stemming from these narratives are inserted on the dimensions global vs local and institutional vs ideological.

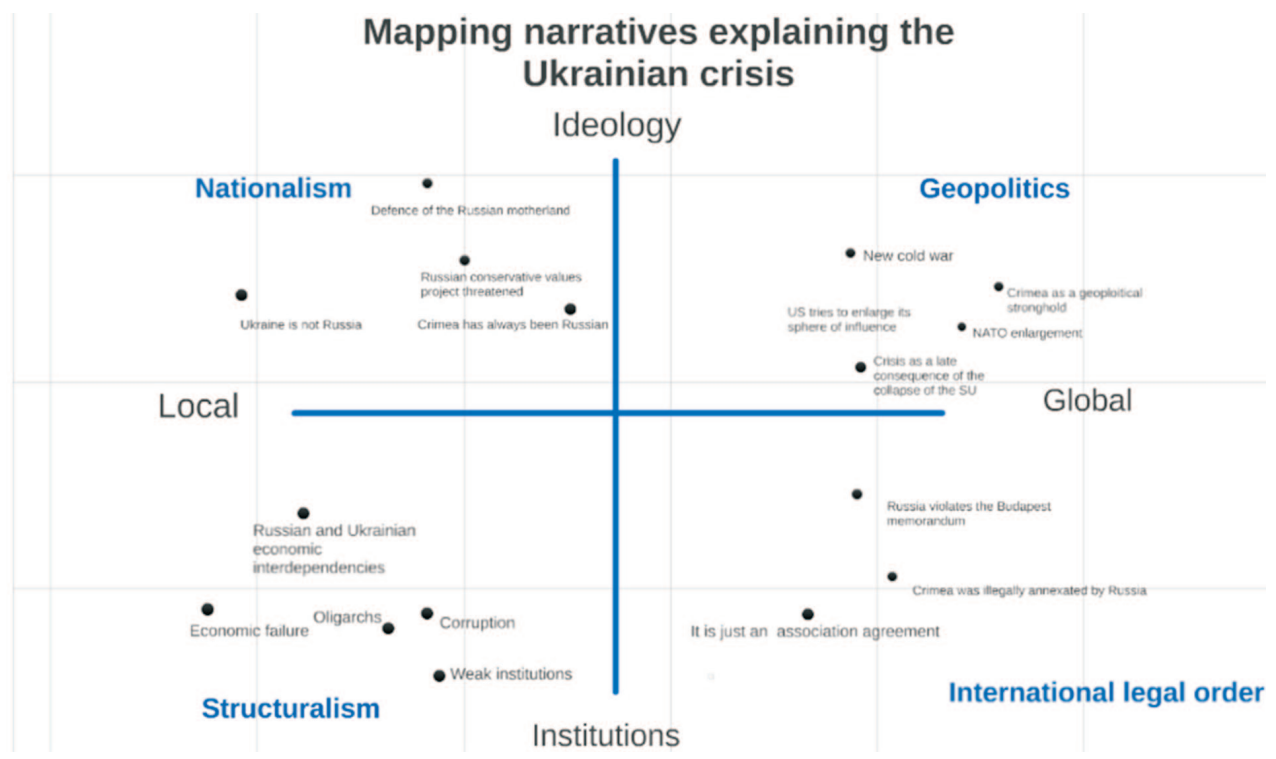

Diagram 1. Map of narratives and interpretations in conceptual space 
This paper further proposed four divisions in Ukrainian national identity, which are extremely helpful while trying to understand contentions stemming from these narratives. The divisions are language, ethnicity, region, and view of history. The narratives are constructed using a selection of elements from one or more of these divisions.

The central argument of this paper has been that a study of the different divisions splitting Ukraine's national identity contributes to a better understanding of the narratives used in the Ukrainian crisis. A closer examination of the divisions in Ukraine's national identity has revealed the origins of a number of arguments that are being used in the information war. Moreover, it also sheds light on the plausibility of some frequently used arguments.

This theoretical framework is summarized in the figure below.

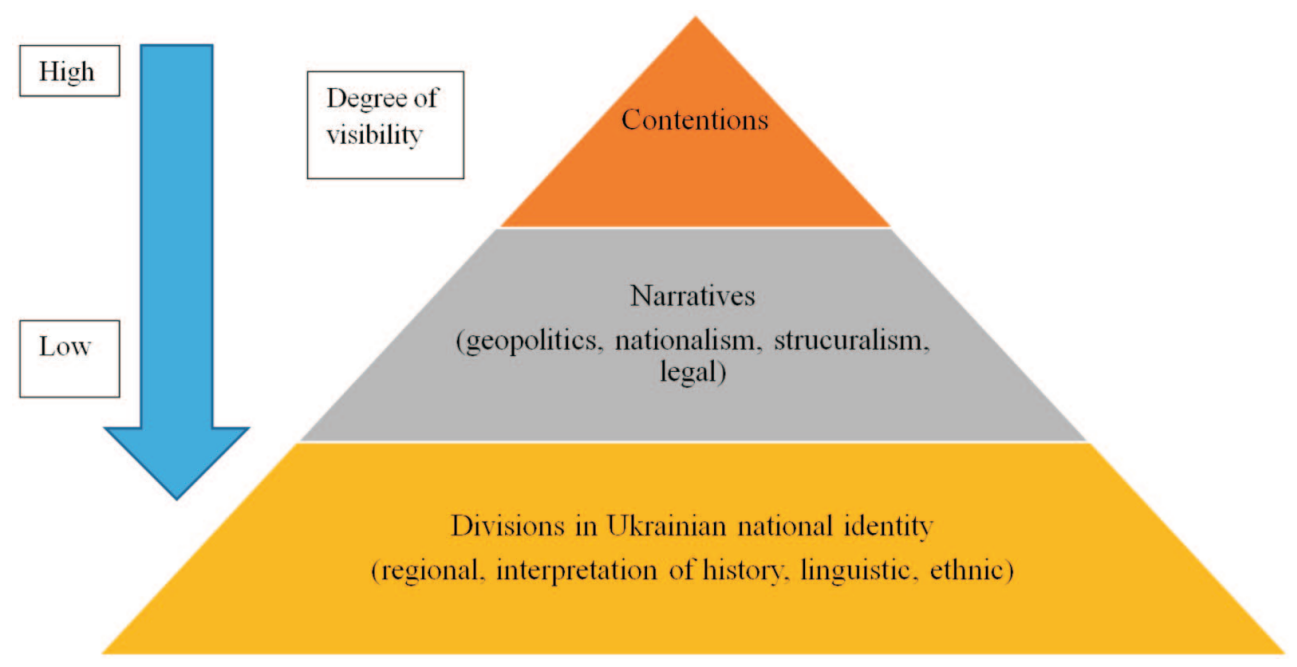

Figure 6. Theoretical framework explaining the Ukrainian crisis

\section{Results}

In this section, two examples of contentions will be discussed to show how divisions in national identity are related to frequently voiced arguments.

Contention 1: There is an East-West divide.

This contention is most often heard in the geopolitical narrative, implying that Ukraine cannot choose between East and West, or, in more radical narratives, it should be split up because it cannot function because it is internally too divided. 
A national identity research by Pirie (1996) and Karácsonyi et al. (2014) showed that the commonly held assumption in Western circles about a geopolitical divide between East and West is questionable. Broadly speaking, Russian-speaking Ukrainians and ethnic Russians living in Ukraine are politically loyal to Ukraine (Jansen 2014: 202). People with a marginally Ukrainian national identification felt betrayed by Kiev but did not support Russia when separatists proved to be poor administrators and showed criminal behaviour (Starink 2015: 294). Ethnic Russians and, to a lesser extent, Russian-speaking Ukrainians do not want a cultural identity forced upon them that is based on ethnic and/or linguistic criteria which are motivated by anti-Russian sentiments, but this does not simply entail that they feel Russian or want to belong to Russia. They are loyal to the Ukrainian state as long as this condition is fulfilled. Mobilization along ethnic or linguistic lines, as was already predicted by Molchanov, did not occur (Molchanov 2002: 206). If a dividing line must be drawn, it would be the Uman-Kharkiv line, which splits the north-west from the south and east. This line corresponds roughly to the forested and mountainous parts of Ukraine vs steppe and Crimea. It divides the predominantly industrial areas historically colonized by Russia, where most ethnic Russians are concentrated from the ethnically more Ukrainian regions, which historically were less attached to Russia. The north-west vs south-east Uman-Kharkiv line is better able to cover the complex situation in Ukraine although it does not coincide with the territories over which Kiev has lost control.

Contention 2: It is understandable that parts of Ukraine which are linguistically, if not ethnically, Russian do not want to drift away from Russia.

This contention is most frequently voiced in the Russian nationalist narrative, but it also occurs in the other narratives. Although the Russian side suggests the contrary, considerable discussion exists about who belongs to the Russian world (Molchanov 2002: 118). As the examples of 'indigenization' in the 1930s and the lack of interest for Crimea in the 1990s showed, Russian political development offers 'a continuity of inconsistency' (Molchanov 2002: 129). Despite efforts in Russia to give answers to those who are longing for national self-consciousness, no clear distinction can be made between who is Russian and who is not. Intermarriage, the legacy of the Soviet Union in terms of Soviet identification and values and the ascent of successor states, such as Ukraine, with ethnically and linguistically mixed populations do not fit well in the simplistic schemes used by nationalists. Socio-historical and cultural differences turned out to be more important than ethnic divisions (Molchanov 2002: 19). The social context (such as the urban-rural divide) is a better predictor for the position in the conflict than ethnic characteristics because high levels of political apathy and mixed marriages make political opinion volatile and blur loyalties. Urban areas with traditional 
industry show the highest correlation with support for closer ties with Russia, not 'the East'. A more assertive foreign policy of Russia abroad only adds to the confusion and polarization. Indeed, it could be argued that Russian interference united Ukraine and stimulated the use of the Ukrainian language, for which the same argument can be made. In Russian nationalist narratives, speaking Russian or Ukrainian means you want to belong to the nation of that language. However, census data about language use show that this core assumption of nationalist narratives is false. A much more complex combination of historical, nationalist, geographic, and value-driven convictions can account for the position taken in the conflict by Russian language speakers. This complex diversity is easily overlooked in a war-like situation where a Russian speaker can easily be taken for a Kremlin supporter (Besters-Dilger 2001: 375).

The nationalist point about the discrimination of ethnic Russians in Ukraine (with geopolitical implications of 'justified Russian interference') seemed a plausible explanation when at some point radicals became very prominent at Maidan. This argument was given a geopolitical dimension with the suggestions that these radicals were supported by the West to weaken Russia.

A closer look at the legal and actual situation revealed that eventually no substantial damage was done to the rights of Russians or Russian speakers, as the law proposal restricting the use of Russian was vetoed. In contrast to the Baltic states, Ukrainian citizenship is still offered to all citizens, and Russian is widely spoken. Radical anti-Russian voices received abundant media attention in Russia, but their respective parties failed to attract many votes in Ukraine. From the Russian angle, much of the Russian narrative about the discrimination of Russian could apply to Latvia and Estonia but not to Ukraine. Maidan and the events that followed can be largely explained by widespread dissatisfaction with the political class due to corruption and criminal methods (Starink 2015: 240). It was not an organized coup to eliminate the rights of ethnic Russians in Ukraine.

In a similar way, the study of the divisions in national identity can help provide meaningful perspectives on the other arguments presented in the introduction, which stem from a certain narrative and rely on a selective use of the divisions.

\section{Acknowledgements}

The author would like to thank Professor Dr Marc Jansen of the University of Amsterdam for giving comments and discussing this working paper and Henri W. Mathon for his thorough intellectual and linguistic input on this paper. 


\section{References}

BARRINGTON, Lowell-HERRRON, Erik. 2004. One Ukraine or Many? Regionalism in Ukraine and Its Political Consequences. Nationalities papers: the Journal of Nationalism and Ethnicity 32(1): 53-86.

BESTERS-DILGER, Johanna. 2001. Aktuelle Sprachsituationen in der Ukraine. In: JORDAN, Peter-KAPPELER, Andreas-LUKAN, Walter-VOGL, Josef (eds), Ukraine: Geographie, Etnische Struktur, Geschichte, Sprache und Literatur, Kultur, Politik, Bildung, Wirtschaft, Recht. Peter Lang, Frankfurt am Main, 497-523.

BOMSDORF, Falk. 2015. Klarheit und Konsequenz, Russland-Politik in Zeiten des Krieges. Osteuropa 65(1-2): 65-71.

CREUZBERGER, Stefan. 2015. Die Legende vom Wortbruch, Russland der Westen und die NATO-Osterweiterung. Osteuropa 65(3): 95-108.

GEISSBÜHLER, Simon. 2014. Einleitung. In: GEISSBÜHLER, Simon (ed.), Kiew - Revolution 3.0, Der Euromaidan 2014/14 und die Zukunftsperspektiven der Ukraine. Ibidem Verlag, Stuttgart, 7-32.

GOLCZEWSKI, Frank. 2011. Die umstrittene Tradition: OUN/UPA und nation-building. In: KAPPELER, Andreas (ed.), Die Ukraine, Prozesse der Nationsbildung. Bohlau, Köln-Weimar-Wien, 319-334.

GRAY, John. 2014. Een kwart eeuw liberale misvattingen. De Groene Amsterdammer/Prospect Magazine 138(44): 30-35.

HAUSMANN, Guido-PENTER, Tanja. 2014. Der Gebrauch der Geschichte, Ukraine 2014: Ideologie vs. Historiographie. Osteuropa 64(9-10): 35-50.

JACOBS, Kristof (ed.). 2016. Het Oekraïne-referendum Nationaal Referendum Onderzoek 2016. http://oekrainee.eu/wp-content/uploads/2016/11/Nationaal $\%$ 20Oekra\%C3\% AFne\% 20Referendum\% 20Onderzoek\% 202016.pdf.

JAHN, Egbert. 2015. Neuauflage des Ost-West-Konflkts. Friedenspolitische Herausforderungen durch die neuen Kriege in Europa. Osteuropa 65(3): 25-45. JANMAAT, Jan Germen. 2000. Nation-Building in Post-Soviet Ukraine, Educational Policy and the Response of the Russian-Speaking Population. Netherlands Geographical Studies, Utrecht Amsterdam.

JANSEN, Marc. 2014. Grensland, Een geschiedenis van Oekraïne. Van Oorschot, Amsterdam.

JORDAN, Peter. 1999. Ethnische Struktur der Ukraine. In: JORDAN, P.KAPPELER, A.-LUKAN, W.-VOGL, J. (eds): Geographie, Ethnische Struktur, Geschichte, Sprache und Literatur, Kultur, Politik, Bildung, Wirtschaft, Recht. Peter Lang, Frankfurt am Main, 55-108.

KAPPELER, Andreas. 2011. Ukrainische und russische Nation: Ein asymnerisches Verhaeltnis. In: KAPPELER, Andreas (ed.), Die Ukraine, Prozesse der Nationsbildung. Böhlau, Köln-Weimar-Wien. 
KARÁCSONYI, Dávid-KOCSIS, Károly-KOVALY, Katalin-MOLNÁR, JózsefPOTI, László. 2014. East-West Dichotomy and Political Right in Ukraine - Was Huntington Right? Hungarian Geographical Bulletin 63(2): 99-134.

KATZ, Mark. 2015. Aggression und Reaktion, Russland, die Ukraine und der Westen. Osteuropa 65(1-2): 57-64.

KOHUT, Zenon. 2011. Making Ukraine. Studies on Political Culture, Historical Narrative and Identity. Canadian Institute of Ukrainian Studies Press, Edmonton, Toronto.

KOROSTELINA, Karina. 2013. Mapping National Identity Narratives in Ukraine. Nationalities Papers: the Journal of Nationalism and Ethnicity 41(2): 293-315. KRZEMINSKI, Adam. 2015. Emanzipation und selbstbehauptung. Die ukrainische Frage, der Westen und Russland. Osteuropa 65(3): 3-23.

LUCHTERHANDT, Otto. 2014. Die Krim-Krise von 2014, Staats- und volkerrechtliche Aspekte. Osteuropa 64(5-6): 61-86.

MAGOCSI, Paul. 1996. A History of Ukraine. University of Toronto Press, Toronto Buffalo London.

MALEK, Martin. 2011. Russische Stimmen zur ukrainischen Nationsbuilding. In: KAPPELER, Andreas (ed.), Die Ukraine, Prozesse der Nationsbildung. Böhlau, Köln-Weimar-Wien. 389-401.

MOLCHANOV, Mikhail. 2002. Political Culture and National Identity in RussianUkrainian Relations. Texas A\&M University Press, College Station.

MOVCAN, Veronika. 2015. Aus dem Zwiscenraum, Ukraine handelsverfelchtung und Aussenpolitik. Osteuropa 65(1-2): 159-169.

MÜNZ, Rainer-OHLIGER, Rainer. 1999. Die Ukraine nach der Unabhängigkeit: Nationsbildung zwischen Ost und West. In: Berichte des Instituts für ostwissenschaftliche und internationale Studien 5.

ONWIJN, Karel. 2005. Oekraïne. KIT Publishers, Amsterdam.

PESENTI, Marina-POMERANTSEV, Peter. 2016. How to Stop Disinformation. Lessons from Ukraine for the Wider World. http://li.com/docs/default-source/ publications/how-to-stop-disinformation-lessons-from-ukraine-for-the-widerworld.pdf.

PIRIE, Paul. 1996. National Identity and Politics in Southern and Eastern Ukraine. Europe-Asia Studies 48(7): 1079-1104.

POLONSKA-VASYLENKO, Natalia. 1968. Two Conceptions of the History of Ukraine and Russia. Ukrainian Publishers, London.

POMERANTSEV, Peter. 2015. Niets is waar en alles is mogelijk, het surrealisitische hart van het nieuwe Rusland. Hollands Diep, Amsterdam.

PORTNOV, Andriy. 2011. Die Ukrainisiche Nationsbildung in der postsowjetischen Historiographie: Einige Beobachtungen. In: KAPPELER, Andreas (ed.), Die Ukraine, Prozesse der Nationsbildung. Böhlau, Köln-Weimar-Wien, 29-49. 
2014. Das Mantra der Nichteinmischung, Glaubenssatze der Putin-freunde. Osteuropa 64(9-10): 5-11.

POTICHNYJ, Peter. 1986. Ukrainians in World War II Military Formations: an Overview. In: BOSHYK, Yury (ed.), Ukraine during World War II: History and Its Aftermath. Canadian Institute of Ukrainian Studies, Edmonton, 61-66.

PRIZEL, Ilya. 1998. National Identity and Foreign Policy, Nationalism and Leadership in Poland, Russia and Ukraine. Cambridge University Press, Cambridge.

RYABCHUK, Mykola. 2011. Gescheiterter Staat oder Erfolgsgeschichte? In: KAPPELER, Andreas (ed.), Die Ukraine, Prozesse der Nationsbildung. Böhlau, Köln-Weimar-Wien, 419-430.

SASSE, Gwendolyn. 2007. The Crimea Question, Identity, Transition, Conflict. Harvard University Press, Cambridge.

SHEIKO, Konstantin-BROWN, Stephen. 2014. History as Therapy, Alternative History and Nationalist Imaginings in Russia 1991-2014. Ibidem Verlag, Stuttgart.

SHULMAN, Stephen. 2004. National Identity and Public Support for Political and Economic Reform in Ukraine. Slavic Review 64(1): 56-87.

SNYDER, Timothy. 2003. The Reconstruction of Nations, Poland, Ukraine, Lithuania, Belarus, 1569-1999. Yale University Press, New Haven London. 2010. Bloedlanden, Europa tussen Hitler en Stalin. Anthos, Amsterdam.

STARINK, Laura. 2015. In de schaduw van de grote broer. Atlas-Contact, Amsterdam-Antwerpen.

VELYCHENKO, Stephen. 1992. National History as Cultural Process. A Survey of the Interpretations of Ukraine's Past in Polish, Russian, and Ukrainian Historical Writing from the Earliest Times to 1914. Canadian Institute of Ukrainian Studies Press, Edmonton.

2000. Rival Grand Narratives of National History: Russian/Soviet, Polish and Ukrainian Accounts of Ukraine's Past (1772-1991). In: Österreichische Osthefte 42: 139-160.

VOSWINKEL, Johannes. 2014. Zynismus mit journalistischem Antlitz, Russlands Medien, die macht und die Ukraine. Osteuropa 64(5-6): 175-191.

WILSON, Andrew. 2014. Ukraine Crisis, What It Means for the West. Yale University Press, New Haven London.

YEKELCHYK, Serhy. 2015. The Conflict in Ukraine, What Everybody Needs to Know. Oxford University Press, Oxford.

YURKEVICH, Myroslav. 1986. Galician Ukrainians in German Military Formations and in the German Administration. In: BOSHYK, Yury (ed.), Ukraine during World War II: History and its Aftermath. Canadian Institute of Ukrainian Studies, Edmonton. 67-89. 